\title{
Researching the Septuagint in South Africa
}

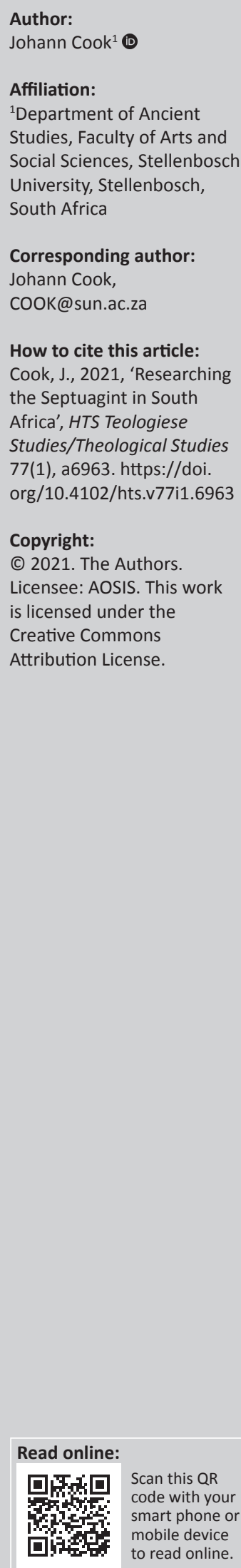

One could argue that the Septuagint is an African document. After all, Alexandria is regarded as the birthplace of the Septuagint - at least the original LXX, namely the Pentateuch. As is well known, the Aristeas letter, inter alia, tells the story of the translation of the Hebrew Bible into Greek after some Jews were forcibly removed from Palestine to Egypt by Ptolemy III and others emigrated for economic reasons (Wright 2015). But this is only one side of the story; there are a number of books that originated elsewhere. Tov mentions the Greek translation of Isaiah (Tov 2010:7). I have identified numerous examples of Jewish exegesis in LXXProverbs and I argued that LXXProv came into being in Palestine (Cook \& Van der Kooij 2012:174). Be that as it may, what is clear is that the Septuagint is being extensively researched throughout Africa, including South Africa. The recent evidence of this ongoing research is the presentation of a number of international congresses with outcomes in the publications of the proceedings. The latest example is the online congress held on 05 and 06 September 2020. The proceedings of this conference together with the contributions of a number of prominent researchers are being published in the international series Vetus Testamentum Supplementum (VTS), entitled The Septuagint South of Alexandria. The volume is edited by Johann Cook and Gideon Kotzé.

\section{LXXSA2020: The Septuagint South of Alexandria}

Bryan Beekman (KU Leuven) (De (Pro)verb(i)is Raris: The Greek Rendering of Hebrew Absolute Hapax Legomena in LXX-Proverbs)

Johann Cook (Stellenbosch University) (PLATONISM AND JUDAISM - Have they ever met? Reflections on the Biblical Creation Stories)

Evangelia Dafni (University of Thesalonici) (Euripides' / Ion and 1 Reigns 1)

Chris de Wet (UNISA) (The Book of Judith in Early Christianity)

Annette Evans (University of the Free State) ('Joint human-angelic praise' in LXX Daniel and 4QSabbath Shirot. Early evidence of Merkebah mysticism?)

Russel Gmirkin (Oregon, USA) (The Text of the Septuagint and its Vorlage)

Risimati Hobyane (North-West University) (Deception and Greed in the Name of Religion: A Greimassian Analysis of the Story of Daniel and the Priests of Bel, in the LXX Additions to Daniel)

Pierre Jordaan and Nicholas Allen (North-West University) (Judith and the Broken Fourth Wall)

Helen Keith (UKZN) (The Man who would be King: Reading Haman's Edict (Esther LXX Add B) Through the Lens of Social Identity)

Gideon Kotzé (North-West University) (Wise and All Surprising Kings: Two Shared Themes in Ecclesiastes 1:16 and the Standard Babylonian Version of the Gilgameš Epic)

Wolfgang Kraus (University of Saarland) (Sin and Forgiveness in the Septuagint)

Siegfried Kreuzer ([Wuppertal/Beth-el] [The Septuagint South of Alexandria-in Antiquity])

Eli Lier (UJ) (Masks in Bible, Targum and Talmud: An Interpretive Study) 


\begin{tabular}{|c|c|c|}
\hline 03 March & $\begin{array}{l}\text { Prof. Hans Ausloos } \\
\text { (Université catholique de Louvain) }\end{array}$ & $\begin{array}{l}\text { 'You shall serve YHWH your } \\
\text { God ...' (Deut 6:13). } \\
\text { Worship in the Hebrew and } \\
\text { Greek Versions of } \\
\text { Deuteronomy }\end{array}$ \\
\hline 10 March & $\begin{array}{l}\text { Prof. Dr Martin Rösel } \\
\text { (Universität Rostock) }\end{array}$ & $\begin{array}{l}\text { Notions of the Temple in the } \\
\text { Old Greek Pentateuch. }\end{array}$ \\
\hline 17 March & $\begin{array}{l}\text { Prof. Evangelia Dafni } \\
\text { (Aristotle University of Thessaloniki) }\end{array}$ & $\begin{array}{l}\text { LXX-Genesis 1-3 in the Book of } \\
\text { Wisdom }\end{array}$ \\
\hline 24 March & $\begin{array}{l}\text { Prof. Dr Wolfgang Kraus } \\
\text { (Universität des Saarlandes) }\end{array}$ & $\begin{array}{l}\text { Hilasterion as Translation of } \\
\text { Various Cultic Items in the } \\
\text { Septuagint and Ancient Greek } \\
\text { Literature }\end{array}$ \\
\hline 31 March & $\begin{array}{l}\text { Dr Dirk Buchner } \\
\text { (Trinity Western University) }\end{array}$ & Worship in LXX Levitikus \\
\hline 07 April & $\begin{array}{l}\text { Prof. Gert Steyn } \\
\text { (Theologische Hochschule Ewersbach) }\end{array}$ & $\begin{array}{l}\text { The Septuagint Odes - An } \\
\text { Orientation }\end{array}$ \\
\hline 14 April & $\begin{array}{l}\text { Dr Peter Nagel } \\
\text { (Stellenbosch University) }\end{array}$ & $\begin{array}{l}\text { How the Septuagint } \\
\text { contributes to the theologies } \\
\text { of Acts } 2 \text { and Hebrews } 1\end{array}$ \\
\hline 21 April & $\begin{array}{l}\text { Dr Annette Potgieter } \\
\text { (Hugenote Kollege, Wellington) }\end{array}$ & $\begin{array}{l}\text { Comparing Ode } 5 \text { and Is } \\
26: 9-20 \text {, some remarks on } \\
\text { worship }\end{array}$ \\
\hline 28 April & $\begin{array}{l}\text { Prof. Johann Cook } \\
\text { (Stellenbosch University) }\end{array}$ & A Concise History of LXXSA \\
\hline
\end{tabular}

Source: Annette Potgieter

Douglas Mangum (University of the Free State) (The Biblical Hebrew Idiom 'Fill the Hand' and its Translation in the Septuagint, Peshitta and the Targums)

Cynthia Miller-Naudé and Jacobus Naudé (UFS) (Generative Syntax and Septuagint Greek)

Peter Nagel (US) (The problem of 'naming' and 'referencing' a Hebrew deit(ies): what do the Hebrew and Greek sources reveal?)

Larry Perkins (TWU) (Divine Distinctiveness in Greek Exodus With Special Focus on the Plague Narrative Ex 7-12)

Gert Prinsloo (University of Pretoria) Life for the Righteous: Perspectives on the Text(s) and Interpretation(s) of Habakkuk 2:1-4 in Ancient Textual Witnesses

Martin Rösel (University of Rostock) (Anthropological Perspectives in the Septuagint Psalms)

\section{Honorary lectures}

An innovative initiative by $\mathrm{Dr}$ Annette Potgieter from the Huguenot College, Wellington and former post-graduate student of Prof. Gert Steyn ${ }^{2}$ is additional evidence that the research into the Septuagint is expanding. A series of lectures was organised in order to honour the contribution of Johann Cook to Septuagintal research. As can be seen in Table 1, there were nine lectures presented on Wednesdays commencing on the 3rd of March through the 28th of April, 2021. The plan is to publish this collection of lectures in the Septuagint and Cognate Studies Series. The editors are Annette Potgieter and Evangelia Dafni. They have also decided to invite a number of scholars who did not contribute towards the lecture series.

2.She completed her DTh under the directorship of Prof. Cilliers Breytenbach from the Humboldt University of Berlin. AOSIS published a revised manuscript of the Humboldt University of Berlin. AOSIS published a revised manuscript of the
dissertation entitled 'Contested body: Metaphors of dominion in Romans 5-8' dissertation entitled 'Contested body: Metapho

\section{Historical thought and source interpretation}

Over the years, a special relationship developed between LXXSA and HTS. Firstly, a number of scholars published their research in HTS. Importantly, a characteristic of this development is that the chief editor of HTS, Prof. Andries van Aarde, decided to publish two volumes of LXXSA as part of HTS. The incorporation of these volumes became part of HTS as two Special Editions, edited by Johann Cook during $2018(74 / 3)$ and $2020(76 / 3)$. This also entailed the change of the name from Hervormde Teologiese Studies to the title Historical Thought and Source Interpretation.

The current HTS collection is published under the auspices of Historical Thought and Source Interpretation and includes 18 contributions. There are seasoned Septuagint scholars such as Arie van der Kooij, Larry Perkins, Hans Ausloos, Cynthia Miller-Naudé and Jacobus Naudé, Martin Rösel and Wolfgang Kraus. Younger, less experienced scholars such as Marieke D'Hondt, Bryan Beeckman and Douglas Mangum are ensuring the future of Septuagint studies is in good hands. There is also a group of scholars who have been engaged in LXX research for a shorter period of time but who have nevertheless had an impact on Septuagint research. Peter Nagel is an appropriate example. To be sure, these scholars have focused on the LXX as a translation of Semitic texts.

However, an independent development took place at the North-West University, where Pierre Jordaan took the lead, together with Nicholas Allen, Risimati Hobanye and others, who focused on the so-called Deutero-canonical books, independent of the Old Greek text. It is clear that the Septuagint is currently being studied holistically and not just on one level. Another characteristic is that the congresses on the LXXSA address not only LXX research but other ancient versions such as the Targumim are also covered. Larry Lincoln presented excellent research on this corpus, as did Eli Lier. Douglas Mangum, inter alia, dealt with the Peshitta. Gideon Kotzé is a newcomer from Stellenbosch and contributes extensively to LXX research.

\section{A future perspective}

The plans to extend research on the LXX in the future are in place. The next annual meeting of LXXSA will take place in Bloemfontein, at the University of the Free State, on 02-03 September 2021. However, this will also be an online meeting. Finally, a Septuagint congress is planned for 03-05 September 2022. The venue will be the same as the one for the congress presented on 17-19 August 2018 at the Stellenbosch University. Johann Cook, Martin Rösel and Wolfgang Kraus will act as presenters. The focus will be on the formulation of a Theology of the Septuagint.

In the final analysis, it is clear that research into the Septuagint in the broad sense of the word is alive and well, and on a 
strong footing. This applies to past as well as to future research. Scholars from all parts of the world are involved in this process (Cook 2020; Cook \& Rösel 2020).

\section{References}

Cook, J., 2020, 'The Septuagint as a holy text - The first "bible" of the early church', HTS Teologiese Studies/Theological Studies 76(4), a6132. https://doi.org/10.4102/ hts.v76i4.6132
Cook, J. \& Rösel, M. (eds.), 2020, Toward a theology of the Septuagint, SCS 74, SBL Press, Leiden.

Cook, J. \& Van der Kooij, A., 2012, Law, prophets, and wisdom on the provenance of translators and their books in the Septuagint version, CBET 68, Peeters, Leuven.

Tov, E., 2010, 'Reflections on the Septuagint with special attention paid to the postPentateuchal translations', in H.V.W. Kraus \& M. Karrer (eds.), Die SeptuagintaTexte, Theologien, Einflüsse 2. Internationale Fachtagung veranstaltet von Septuaginta Deutsch (LXX.D), pp. 3-23, Wuppertal 23-27 August 2008, WUNT 252, Mohr Siebeck, Tübingen.

Wright, III. B.G., 2015, The letter of Aristeas: Aristeas to 'Philocrates' or on the law of the Jews, De Gruyter, Boston, MA. 